\title{
Ballast water as a vector for tintinnid transport
}

\author{
Richard W. Pierce ${ }^{1, *}$, James T. Carlton ${ }^{2}$, Deborah A. Carlton ${ }^{2}$, Jonathan B. Geller ${ }^{3}$ \\ 'Smithsonian Environmental Research Center, P.O. Box 28, Edgewater, Maryland 21037, USA \\ ${ }^{2}$ Maritime Studies Program, Williams College, Mystic Seaport, Mystic, Connecticut 06355, USA \\ ${ }^{3}$ Department of Biological Sciences, University of North Carolina, Wilmington, North Carolina 28403, USA
}

\begin{abstract}
Ballast tanks of cargo ships arriving in Coos Bay, Oregon, USA, from various Japanese ports were sampled from October 1987 to January 1991. A total of 33 tintinnid species from 15 genera were identified from ballast water samples. Live tintinnids were observed on occasion. Many of the species that were observed in these ballast water samples have also been found in the nearby Strait of Juan de Fuca, but others have never been reported in the eastern Pacific. The presence of tintunnids in ballast water obfuscates any conclusions about the natural distributions of these species. This study suggests that ballast water has been a vector for tuntinnid transport for many years, and that tt may no longer be possible to determine the native distributions for many tintinnid species
\end{abstract}

KEY WORDS: Tintinnid Ciliate - Exotic organisms - Ballast water B Bogeography

Ballast water has long been known to be a vector for the introduction of exotic organisms (Carlton 1985). Among the best-known invasions are the introduction of the zebra mussel into the Great Lakes and the transport of toxic dinoflagellates around the world. Except. for diatoms and dinoflagellates, however, little attention has been directed towards the transport of protists in ballast water.

Tintinnids are the best known ciliates in the marine plankton. They are heterotrophic ciliates characterized by the secretion of a lorica. Tintinnids produce loricae in a diverse array of shapes and sizes. These loricae are sturdy enough to withstand collection in plankton nets and preservation in formalin, and thus have been known about for over a century. Tintinnids and other ciliates are a major component of marine microbial food webs and may have significant impacts on the total food web structure (reviewed in Pierce \& Turner 1992, Sherr \& Sherr 1994). Although it is unclear what effect introduced tintinnids or other ciliates might have

·E-mail: pierce@serc.si.edu on a local food web, the role of protists as exotic invaders must be considered in light of the fact that many invasions have already occurred. Even if these invasions have not had noticeable impacts on food web dynamics, they will still alter our understanding of the biogeography and evolution of marine protists.

Methods. Ships arriving in Coos Bay, Oregon, USA, from various Japanese ports were sampled from 1986 to 1991 . In each vessel, 5 to 6 vertical tows were made with an $80 \mu \mathrm{m}$ mesh, $0.5 \mathrm{~m}$ diameter plankton net. The net was towed at $0.5 \mathrm{~m} \mathrm{~s}^{-1}$ in 10 to $20 \mathrm{~m}$ of water in floodable ballast holds. Samples were examined alive with a stereomicroscope before being preserved. The initial examination of these samples found 367 protistan and metazoan taxa. These results were presented by Carlton \& Geller (1993). Carlton \& Geller concentrated on metazoans present in the ballast water, but noted that unidentified tintinnids were often abundant.

All samples noted to contain tintinnids were subsequently reexamined by $\mathrm{R}$. W. Pierce with a compound microscope. These comprised a subset of 56 out of the 159 ships sampled from a time period between October 1987 and January 1991. Each sample was mixed well, and then allowed to settle for 1 to $2 \mathrm{~min}$. This allowed much of the heavier particulate matter to settle to the bottom of the jar, leaving tintinnids and other lighter matter suspended. A $1 \mathrm{ml}$ aliquot was then pipetted from the suspended fraction and examined in a Sedgewick-Rafter cell. Tintinnids were identified to species on the basis of lorica morphology, and were categorized from rare to abundant based on the number of loricae in the aliquot. Although the samples were collected quantitatively, many tintinnid species may have been undersampled by the $80 \mu \mathrm{m}$ mesh net used to collect the samples. Thus, the samples were treated as qualitative, and no more detailed abundance estimates were practical. 
Results and discussion. A total of 33 tintinnid species from 15 genera were observed (Table 1). Live tintinnids were occasionally noted at the time of original sample examinations, but no specific effort was made to systematically search for live tintinnids. The most frequently abserved species in the preserved samples were Favella taraikaensis, Parafavella gigantea, Eutintinnus lusus-undae, Tintinnopsis tenuis, Ptychocylis obtusa, and Codonellopsis mobilis. Three species ( $P$. gigantea, E. lusus-undae, and C. mobilis) were observed in the samples noted to contain live tintinnids.

Of the 33 species observed, 21, or $64 \%$, were from genera known to be neritic (Pierce \& Turner 1993). Of the neritic genera, Tintinnopsis was represented by the greatest number of species. Favella was the most ubiquitous genus and was present in all but 14 samples. Like Tintinnopsis, Codonellopsis mobilis also agglomerates mineral particles on its lorica, and can be considered a neritic species. Of the 6 species found to be abundant in at least 1 ballast tank, all but Amphorides quadrilineata are neritic species. Most ships are ballasted in port and will typically entrain the neritic and estuarine organisms living there.

Several of the tintinnids observed are notable as new records for the eastern Pacific. One of these new records is Codonellopsis mobilis, previously reported only from the coast of China (Wang 1936). Other new records include typical Japanese tintinnids such as Favella taraikaensis, Tintinnopsis akkeshiensis, Tintinnopsis ampla, Tintinnopsis japonica, and Tintinnopsis tenuis. Since Japanese literature was the primary reference material for tintinnids (Hada 1932a, b, c, 1937), few species were observed which could be considered to be new records for Japan. Rhabdonellopsis apophysata and Steenstrupiella steenstrupii are 2 such species. These species are widespread throughout the warmer waters of the Pacific, so it is uncertain exactly where they were entrained or how long they had been in the ballast tanks.

One tintinnid observed in the ballast water samples has a very interesting history. Hada (1964) described a new tintinnid, Tintinnopsis corniger, from Japanese waters. This tintinnid is notable because it produces a relatively large lorica (approximately $300 \mu \mathrm{m}$ long by $50 \mu \mathrm{m}$ wide) and has a unique, branching, hyaline projection on the aboral end of the lorica. The same tintinnid, named Rhizodomus tagatzi, was earlier described from Peter the Great Bay, Russia (Strelkov \& Wirketis 1950). The significance of Hada's (1964) report is that this species was not reported in earlier works from Japanese waters (Hada 1932a, b, c, 1937) but is routinely reported from later works (Nakashima \& Kimoto 1987. Nomura et al. 1992, Kamiyama 1994). Since it seems unlikely that Hada could have overlooked this
Table 1 Tintinnids observed in ballast water and their maximum observed abundance. Rare: 1 to 2 ; uncommon: 3 to 6 common: 7 to 20 ; abundant: $>20$ loricae per $1 \mathrm{ml}$ aliquot

\begin{tabular}{|c|c|c|}
\hline Species & $\begin{array}{l}\text { Maximum } \\
\text { abundance }\end{array}$ & $\begin{array}{c}\text { No. of } \\
\text { samples }\end{array}$ \\
\hline Acanthostmella norvegica & Rare & 1 \\
\hline Amphorides quadrilineata & Abundant & 4 \\
\hline Codonellopsis mobilis & Abundant & 9 \\
\hline Eutintinnus fraknoi & Common & 1 \\
\hline Eutintinnus lusus-undae & Common & 15 \\
\hline Eutintinnus rectus & Uncommon & 1 \\
\hline Eutintinnus tubulosus & Rare & 1 \\
\hline Favella ehrenbergii & Abundant & 6 \\
\hline Favella taraikaensis & Abundant & 25 \\
\hline Helicostomella fusiformis & Uncommon & 2 \\
\hline Helicostomella subulata & Rare & 4 \\
\hline Leprotintinnus pellucidus & Uncommon & 7 \\
\hline Parafavella denticulata & Common & 7 \\
\hline Parafavella gigantea & Common & 19 \\
\hline Ptychocylis obtusa & Uncommon & 10 \\
\hline Rhabdonellopsis apophysata & Rare & 1 \\
\hline Salpingella acuminata & Rare & 2 \\
\hline Steenstrupiella steenstrupii & Rare & 1 \\
\hline Stenosemella nivalis & Rare & 2 \\
\hline Tintinnidium sp. & Rare & 1 \\
\hline Tintinnopsis akkeshiensis & Rare & 1 \\
\hline Tintinnopsis ampla & Abundant & 2 \\
\hline Tintinnopsis beroidea & Rare & 1 \\
\hline Tintunnopsis corniger & Rare & 2 \\
\hline TIntinnopsis directa & Rare & 1 \\
\hline Tintmnopsis japonica & Uncommon & 1 \\
\hline Tintinnopsis kofoidi & Uncommon & 5 \\
\hline Tintinnopsis lobiancoi & Rare & 1 \\
\hline Tintinnopsis lohmanni & Uncommon & 3 \\
\hline Tintinnopsis radix & Common & 7 \\
\hline Tintinnopsis rapa & Rare & 3 \\
\hline Tintinnopsis tenuis & Abundant & 14 \\
\hline Tintinnopsis tubulosa & Uncommon & 1 \\
\hline
\end{tabular}

tintinnid if it had been present in the 1930s, it is an obvious candidate as an exotic invader to Japanese waters. Its presence in ballast water samples suggests this is one possible mechanism of transport for this species. Tintinnopsis corniger has also been reported in the Gulf of Mexico (Balech 1968, Lubel 1974), and collected from southern California (R. W Pierce unpubl. data) but detailed studies have not established if these are truly the same species.

What are the chances that tintinnids can become established as exotic introductions? Approximately 35000 to 40000 merchant ships are active in the world's oceans (Carlton 1985, Carlton \& Geller 1993) As many as 9 tintinnid species were observed in a single ballast water tank, although 2 to 5 species were typical. Tintinnids were present in approximately $1 / 3$ of all vessels examined, approximately the same percentage (24 of 86) observed in the ballast tanks of ships in St. Lawrence Seaway (Subba Rao et al. 1994). Thus, at 
any given moment, thousands of ships may be moving dozens of tintinnid species around the world's oceans, along with hundreds of other species of protists and metazoans (Carlton \& Geller 1993). It should also be noted that ballast water has been in use for approximately 100 yr. Thus it is highly likely that some tintinnid species have been successfully established in new locations due to ballast water transport.

Is there currently any evidence for the introduction of tintinnids through ballast water? It is impossible to say for certain that any unexplained patterns we may see are definitely due to ballast water, but for neritic tintinnids found on both sides of the Pacific Ocean, ballast water is certainly one possible dispersal mechanism. A problem in detecting exotic species is that few harbors across the world have been comprehensively surveyed for tintinnids, including Coos Bay. Also, since ballast water has been in use for over a century, any surveys conducted in this century or in the future may already have been tainted by introduced exotics.

Detecting protists as exotic organisms presents many problems. The taxonomy and systematics of many protist groups are poorly known. Although tintinnids may be considered to be well known, there are still many unresolved taxonomic problems in this group. Among less well known groups, such as aloricate ciliates and flagellates, only a fraction of all species have been described. It is likely that many introductions have already occurred without any noticeable effects, but when certain organisms are introduced, the results can greatly perturb the ecosystem and restructure the food web. Even when introduced organisms do not cause obvious ecological problems, they may still displace native species, causing a loss in diversity, and confound biogeographic and evolutionary studies. Ballast water introductions will continue to occur for the foreseeable future, so areas at risk need to be surveyed to determine the present protist community and monitored to determine the introduction and effects of introduced protists.

Acknowledgements. We thank Jefferson T Turner and Andrea Locke, who functioned as intermediaries in suggesting and $\mathrm{fa}_{\mathrm{a}}$ cilitating the initial contact that resulted in this collaboration.

This note was submitted to the editor

\section{LITERATURE CITED}

Balech E (1968) Algunas especies nuevas o interesantes de tintinnudos del Golfo de Mexico y Caribe. Revta Mus Argent Cienc Nat Bernardino Rivadavia Inst Nac Invest. Cienc Nat Hidrobiol 2:165-197

Carlton JT (1985) Transoceanic and interoceanic dispersal of coastal marine organisms: the biology of ballast water Oceanogr. Mar Biol Annu Rev 23:313-374

Carlton JT, Geller JB (1993) Ecological roulette: the global transport of nonindigenous marine organisms. Sclence $261: 78-82$

Hada Y (1932a) Descriptions of two new neritic Tintinnoinea, Tintinnopsis japonica and Tps. kofoidi with a brief note on an unicellular organisms parasitic on the latter Proc Imp Acad Japan 8:209-212

Hada Y (1932b) The Tintinnoinea from the Sea of Okhotsk and its neighborhood. J Fac Sci Hokkaido Univ 2:37-59

Hada Y (1932c) Report of the biological survey of Mutsu Bay. 24. The pelagic ciliata, suborder Tintinnoinea. Sci Rep Tohoku Univ 7:553-573

Hada Y (1937) The fauna of Akkeshi Bay IV The pelagic ciliata. J Fac Sci Hokkaido Univ 5:143-216

Hada $Y$ (1964) New species of the Tintinnida found from the $1 \mathrm{n}$ land Sea. Bull Suzugamine Womens's Col Nat Sci 11:1-4

Kamiyama T (1994) The impact of grazing by microzooplankton in northern Hiroshima Bay, the Seto Inland Sea, Japan. Mar Biol 119:77-88

Lubel MAA (1974) Distribucion de los tintinnidos (Protozoa, Ciliateal de la parte oeste, suroestc y sur del Golfo de Mexico. Revta Soc Mex Hist Nat 35:45-76

Nakashıma J, Kimoto K (1987) Comparison of the two counting methods for microzooplankton. Bull Seikai Reg Fish Res Lab 64:77-82

Nomura H, Ishimaru T, Murano M (1992) Microzooplankton. assemblage and its seasonal variation in Tokyo Bay, Japan. Mer Tokyo 30:57-72

Pierce RW, Turner JT (1992) Ecology of planktonic ciliates in marine food webs. Rev Aquat Sci 6:139-181

Pierce RW, Turner JT (1993) Global biogeography of marine tintinnids. Mar Ecol Prog Ser 94:11-26

Sherr EB, Sherr BF (1994) Bacterivory and herbivory: key roles of phagotrophic protists in pelagic food webs. Microb Ecol 28:223-235

Strelkov AA, Wirketis MA (1950) A new planktonic infusorian of the suborder Tintinnoinea from Peter the Great Bay. Dokl Akad Nauk SSSR 74:389-391

Subba Rao DV. Sprules WG, Locke A, Carlton JT (1994) Exotic phytoplankton from ships' ballast waters: risk of potential spread to mariculture sites on Canada's East Coast. Can Data Rep Fish Aquat Sci 937:1-51

Wang CC (1936) Notes on Tintinnoinea from the Gulf of PéHai. Sinensia 7:353-370

Manuscript first received: September 23, 1996

Revised version accepted: February 5, 1997 